\title{
PERAN CITRA MEREK DALAM MEMEDIASI PENGARUH E-WOM TERHADAP MINAT BELI SEPATU MEREK BATA
}

\author{
Gusti Agung Narendra Iswara ${ }^{1}$ \\ I Wayan Santika ${ }^{2}$
}

\author{
${ }^{1,2}$ Fakultas Ekonomi dan Bisnis Universitas Udayana (Unud), Bali, Indonesia \\ e-mail: gustiagungnarendra1996@gmail.com
}

\begin{abstract}
ABSTRAK
Penelitian ini menjelaskan peran citra merek memediasi pengaruh E-WOM terhadap minat beli. Penelitian ini dilakukan di kota Denpasar yang melibatkan 130 responden. Penelitian menggunakan kuesioner, observasi dan wawancara. Digunakan analisis jalur dan uji sobel. Hasil penelitian adalah variabel $E-W O M$ mempengaruhi positif serta signifikan pada citra merek, E-WOM mempengaruhi positif serta signifikan pada minat beli, citra merek mempengaruhi positif serta signifikan pada minat beli, dan citra merek mampu dalam memediasi $E$-WOM dengan minat beli. Pihak manajemen Bata hendaknya meningkatkan keyakinan persepsi calon pembeli dengan pengguna yang sudah pernah menggunakan sepatu merek Bata di media sosial, dengan cara mereview keunggulan produk Bata.
\end{abstract}

Kata kunci: citra merek, $E-W O M$, minat beli.

\begin{abstract}
This study explains the role of brand image mediating the influence of E-WOM on buying interest. This research was conducted in the city of Denpasar involving 130 respondents. The study used questionnaires, observation and interviews. Path analysis and sobel test were used. The results of this study are E-WOM variables that influence positively and significantly on brand image, E-WOM has a positive and significant influence on buying interest, brand image has positive and significant influence on buying interest, and brand image is able to mediate E-WOM with buying interest. Bata management should increase the perception of prospective buyers with users who have used Bata brand shoes on social media, by reviewing the superiority of Bata products.
\end{abstract}

Keywords: brand image, E-WOM, buying interest 


\section{PENDAHULUAN}

Persaingan antar perusahaaan semakin ketat, karena setiap perusahaan senantiasa berusaha untuk mendapatkan profit atau keuntungan yang maksimal. Persaingan yang semakin ketat dapat terjadi disebabkan oleh banyak kemajuan dan perubahan yang terjadi dalam dunia bisnis, salah satunya ditandai dengan adanya perubahan pola pikir masyarakat yang semakin berkembang, kemajuan teknologi dan gaya hidup yang tidak lepas dari pengaruh globalisasi. Selain itu, perkembangan teknologi menyebabkan terjadinya perubahan yang signifikan dalam hal mencari informasi pada era peradaban baru yaitu era teknologi informasi. Majunya teknologi informasi membuat semakin banyak dari calon konsumen mencari informasi yg dibutuhkan pada suatu produk sebelum akhirnya diputuskan untuk membeli.

Kemajuan yang sangat pesat dalam dunia teknologi informasi menuntut para pelaku usaha untuk dapat memahami serta memanfaatkannya dalam kegiatan bisnis sebagai upaya untuk meningkatkan daya saing (Harun, 2017). Salah satu hasil kemajuan teknologi informasi yang berkontribusi besar terhadap perubahan ini adalah internet. Goldsmith dan Horowitz (2006) dalam Christie (2016) menyatakan bahwa penggunaan internet telah mengubah cara konsumen berkomunikasi dalam berbagi pendapat dan ulasan mengenai produk atau jasa yang pernah dikonsumsi.

Komunikasi E-WOM tentu membuat perubahan bagi perkembangan dunia bisnis untuk bersaing dalam melakukan kegiatan pemasaran. Menurut Abubakar et al. (2016) menyebutkan jika $E$-WOM bermacam pernyataan baik serta buruk yg diciptakan oleh seseorang serta pelanggan akan sebuah produk, pelayanan serta perusahaan yg tersedia utk masyarakat luas menggunakan internet. Mengandalkan berbagai informasi dan pendapat positif dari orang lain yang diperoleh melalui internet terkait suatu merek dapat disimpulkan bahwa $E$-WOM memiliki dampak penting pada niat pembelian konsumen (Cong dan Zheng, 2017). Berdasarkan ketiga pernyataan tersebut, dapat diketahui bahwa $E$-WOM juga bisa memainkan peran yang sangat besar dalam melihat ketertarikan konsumen mengenai merek yang baru dipasar, begitu pula sebaliknya. Salah satu perusahaan yang memanfaatkan perkembangan internet dalam hal E-WOM adalah perusahaan Bata.

Pengoperasian perusahaan Bata di Indonesia dijalankan oleh PT. Sepatu Bata, Tbk. Pabrik perusahaan ini pertama kali berdiri pada Tahun 1939, dan saat ini produksinya berada di dua tempat, yaitu Kalibata dan Medan. Hasil produksi dari PT. Sepatu Bata, Tbk. Kemudian didistribusikan ke seluruh Indonesia termasuk wilayah Bali. Bata kini mengeluarkan jenis sepatu seperti sepatu kasual, sepatu olahraga, sepatu sekolah remaja, sepatu kerja pria, sepatu kerja perempuan. Perusahaan Bata memanfaatkan perkembangan internet dalam hal ini yaitu $E-W O M$ dalam memasarkan produknya melalui internet seperti Openrice.com (review sharing plat-form), TokoBagus (online shop), KASKUS (online community), blog, Facebook (social media). Asosiasi Persepatuan Indonesia (Aprisindo), 2017.

Data Market Share per Tahun 2017, dapat dilihat bahwa ada beberapa merek yang tergolong empat kategori terbaik dalam jenis produk masing masing, di antaranya ada Bata, Nike, Converse, Adidas, Reebok (Aprisindo, 2017). Berikut ini adalah data Market Share yang dimana disajikan dalam Tabel 1. 
Tabel 1.

Market Share Produk Sepatu APRISINDO 2017

\begin{tabular}{|c|c|c|c|c|c|}
\hline \multirow[b]{2}{*}{$\begin{array}{l}\text { Nama } \\
\text { Merek }\end{array}$} & \multicolumn{4}{|c|}{ Kategori Produk (\%) } & \multirow[b]{2}{*}{$\begin{array}{c}\text { Sepatu } \\
\text { Kerja } \\
\text { Perempuan }\end{array}$} \\
\hline & $\begin{array}{l}\text { Sepatu } \\
\text { Kasual }\end{array}$ & $\begin{array}{c}\text { Sepatu } \\
\text { Olahraga }\end{array}$ & $\begin{array}{c}\text { Sepatu } \\
\text { Sekolah Remaja }\end{array}$ & $\begin{array}{c}\text { Sepatu } \\
\text { Kerja Pria }\end{array}$ & \\
\hline Bata & $27 \%$ & $4,3 \%$ & $4,1 \%$ & $22 \%$ & $15,5 \%$ \\
\hline Nike & $18 \%$ & $30 \%$ & $6 \%$ & & \\
\hline Converse All Star & $17 \%$ & & $3,5 \%$ & & \\
\hline Adidas & $5,4 \%$ & $23 \%$ & & & \\
\hline Reebok & & $6,3 \%$ & & & \\
\hline Eagle & & $3,7 \%$ & & & \\
\hline Ardiles & & $3,7 \%$ & & & \\
\hline Tomskins & & & $3,8 \%$ & & \\
\hline League & & & $3,2 \%$ & & \\
\hline Fladeo & & & & $10 \%$ & $19 \%$ \\
\hline Carvil & & & & $7,8 \%$ & \\
\hline
\end{tabular}

Sumber: Asosiasi Persepatuan Indonesia (Aprisindo), 2017

Pada kategori produk sepatu kasual dan sepatu kerja pria menunjukkan Bata menempati posisi pertama dengan memperoleh data market share sebesar $27 \%$ pada kategori produk sepatu kasual dan $22 \%$ pada kategori produk sepatu kerja pria yang dimana minat beli konsumen terhadap produk sepatu Bata hanya pada kategori sepatu kasual dan sepatu kerja pria.

Citra merek dari suatu perusahaan di Indonesia sering diukur dengan adanya data Top Brand Index. Top Brand Index adalah sebuah penghargaan yang diberikan kepada merek-merek yang meraih predikat yang diberikan berdasarkan penilaian yang diperoleh dari hasil survei berskala nasional. Top Brand Index diukur dengan menggunakan tiga parameter, yaitu didasarkan atas merek yang pertama kali disebut oleh responden ketika kategori produknya disebutkan, berdasarkan pada merek yg paling terakhir dipakai serta dikonsumsi oleh responden serta terakhir berdasarkan pada merek yg ingin dipakai serta dikonsumsi dikemudian hari.

Nilai dari masing-masing parameter utk sebuah merek pada kategori produk tertentu didapatkan menggunakan cara perhitungan persentase frekuensi merek itu relatif pada frekuensi seluruh merek, namun hanya merek-merek yang memperoleh Top Brand Index minimum sebesar $10 \%$ dan merek-merek yang menurut hasil survei berada dalam posisi tiga terbaik di dalam kategori produknya. Kedua kriteria ini harus dipenuhi oleh sebuah merek agar berhak menyandang predikat Top Brand.

Tabel 2. dibawah menunjukan data hasil survei Top Brand Index dalam jangka waktu lima Tahun terakhir, memperlihatkan Bata berada pada posisi pertama terhadap keseluruhan merek-merek sepatu yg terdapat di Top Brand Index sehingga Bata merupakan pemimpin pasar dalam lima tahun belakangan. Tingkat dari persentase Top Brand Index Bata sebesar 25,3\% pada tahun 2014. Persentase Top Brand Index Bata pada tahun 2015 terdapat peningkatan yg lumayan signifikan dari $1,8 \%$ ke $27,1 \%$ dikarenakan hal tersebut Bata berada di posisi yg terdepan dibanding pesaing industri sepatu lain. Tingkat persentase Top Brand Index Bata pada tahun 2016, terjadi penurunan yg drastis pada tingkat 7,9\% ke 19,2\%. Begitu pula pada Tahun 2017, tingkat dari persentase Top Brand Index pada 19,3\%. 
Sedangkan, pada 2018 tingkat persentase Top Brand Index pada produk sepatu Bata terjadi penurunan sebesar $2,4 \%$ menjadi $16,9 \%$. Berbeda halnya dengan kuantitas penjualan, penjualan sepatu Bata pada tahun 2016 memperoleh keuntungan sebesar 999.802.379 Juta Rupiah, namun pada tahun 2017 mengalami penurunan penjualan menjadi sebesar 974.536.083 Juta Rupiah (Annual Report PT. Sepatu Bata Tbk, 2017).

Tabel 2.

Top Brand Produk Sepatu 2014-2018

\begin{tabular}{lrrrrr}
\hline \multicolumn{1}{c}{ Merek } & $\mathbf{2 0 1 4}$ & $\mathbf{2 0 1 5}$ & $\mathbf{2 0 1 6}$ & $\mathbf{2 0 1 7}$ & $\mathbf{2 0 1 8}$ \\
\hline Bata & $25,3 \%$ & $27,1 \%$ & $19,2 \%$ & $19,3 \%$ & $16,9 \%$ \\
Nike & $17,9 \%$ & $18,1 \%$ & $12,4 \%$ & $12,2 \%$ & $9,3 \%$ \\
Converse & $17,3 \%$ & $17,0 \%$ & $6,4 \%$ & $6,3 \%$ & - \\
Adidas & $4,9 \%$ & $5,4 \%$ & $11,5 \%$ & $11,2 \%$ & - \\
Fladeo & - & - & $6,1 \%$ & $6,5 \%$ & $11,7 \%$ \\
Yongki & - & - & $4,9 \%$ & $4,7 \%$ & $8,2 \%$ \\
Komaladi & & & & &
\end{tabular}

Sumber: Asosiasi Persepatuan Indonesia (Aprisindo), 2017

Tabel 3.

Hasil Pernyataan Pra-Survei

\begin{tabular}{clccc}
\hline \multirow{2}{*}{ No. } & \multicolumn{1}{c}{ Pertanyaan } & \multicolumn{2}{c}{ Jawaban } & $\begin{array}{c}\text { Jumlah } \\
\text { Responden }\end{array}$ \\
\cline { 3 - 3 } & \multicolumn{1}{c}{ Ya } & Tidak & \\
\hline 1 & $\begin{array}{l}\text { Apakah anda mengetahui namun } \\
\text { belum pernah membeli produk sepatu } \\
\text { merek Bata? }\end{array}$ & 31 & 3 & 34 \\
2 & $\begin{array}{l}\text { Apakah anda memiliki persepsi yang } \\
\text { sama terhadap reviewer online } \\
\text { produk sepatu merek Bata? }\end{array}$ & 29 & 5 & 34 \\
$3 \quad \begin{array}{l}\text { Apakah anda tidak kesulitan } \\
\text { mengingat produk sepatu merek }\end{array}$ & 25 & 9 & 34 \\
$\begin{array}{l}\text { Bata? } \\
\text { Apakah diferensiasi produk Bata } \\
\text { kurang inovatif dibandingkan } \\
\text { pesaingnya sebagai minat anda untuk } \\
\text { membeli produk merek Bata? }\end{array}$ & 1 & 33 & 34 \\
\hline Sumber: Asosiasi Persepatuan Indonesia (Aprisindo), 2017 & & \\
\hline
\end{tabular}

Peneliti melakukan pra survei terhadap 34 responden di Kota Denpasar. Berdasarkan hasil pra survei yang dilakukan pada 34 responden di Kota Denpasar dapat dijelaskan bahwa dari 34 responden, terdapat 31 responden mengetahui namun belum pernah membeli produk sepatu merek Bata dan tiga responden menjawab tidak. Sebanyak 29 responden menjawab memiliki persepsi yang sama 
terhadap reviewer online sepatu merek Bata dan lima responden lain menjawab tidak. Berdasarkan hasil pra survei pada pertanyaan ketiga bahwa 25 responden menjawab bahwa responden tidak kesulitan mengingat produk sepatu merek Bata. dan 9 responden lain menjawab tidak. Berdasarkan hasil pra surevei pada pertanyaan keempat bahwa satu responden menjawab diferensiasi produk Bata kurang inovatif dibandingkan pesaingnya mempengaruhi minat untuk membeli produk sepatu merek Bata dan 33 responden menjawab tidak. Hasil pra survei menunjukan bahwa diferensiasi produk Bata kurang inovatif dibandingkan pesaingnya. Berdasarkan hal tersebut, Bata mendapatkan kesan yang baik dari konsumen serta mendapatkan $E-W O M$ yang positif dari konsumen secara tidak langsung akan meyakinkan serta menumbuhkan niat beli pada konsumen. Dengan mengandalkan banyak informasi yg bermanfaat serta pendapat dari orang berbeda yg baik terkait dgn sepatu merek Bata hingga $E$-WOM bisa mendorong adanya citra merek dari perusahaan Bata. Melihat itu diharap perusahaan Bata dapat membuat citra merek yg baik supaya produk yg dipasarkannya dapat bertahan lama pada pasaran serta bersaing dengan produk pesaingnya dan bisa menambahkan minat beli.

Fenomena di atas menunjukkan bahwa terjadi penurunan minat pembelian konsumen terhadap produk sepatu secara umum. Hal tersebut juga terjadi pada merek sepatu Bata yang mengalami penurunan penjualan, jauh dengan kenyataannya bahwa Bata merupakan Top Brand Index pada Tahun 2014-2018. Hal berbeda yang didapatkan dari hasil pra survei menunjukkan bahwa penyebab terjadinya fenomena tersebut dikarenakan bahwa sepatu Bata mengalami penurunan penjualan di kalangan konsumen dikarenakan banyaknya pesaing yang muncul dengan diferensiasi produk sepatu Bata sendiri yang masih belum dapat memuaskan pangsa pasar di Indonesia dibandingkan pesaing-pesaingnya yang memiliki diferensiasi tersendiri terhadap produknya sehingga mudah untuk dikenal oleh konsumen dan pada era peradaban baru yaitu era peradaban generasi digital yang dimana masyarakat sudah terkena pengaruh internet secara menyeluruh tidak terkecuali generasi milenial yang dimana generasi milenial tidak terlepas dari gadget sehingga generasi milenial terlebih dahulu mencari informasi mengenai suatu produk sebelum melakukan pembelian, lebih banyak mendapatkan review online dari internet akan suatu produk, jika komunikasi E-WOM yang didapatkan mengenai suatu produk baik maka akan semakin tinggi minat beli konsumen, namun fenomena yang didapat bahwa komunikasi $E$-WOM mengenai sepatu merek Bata kurang diminati bagi generasi milenial karena review online mengenai produk sepatu merek Bata rendah.

Menurut Randi dkk. (2016), menyebutkan jika minat beli adalah salah satu tahap penting yg harus diperhitungkan oleh pemasar hal tersebut karena minat adalah suatu kondisi yg mendahului seseorang dalam mempertimbangkan serta membuat keputusan utk memutuskan memakao sebuah produk serta layanan jasa. Kemudian Schiffman \& Kanuk (2008:206) didalam Maghfiroh (2016), menyebutkan jika minat beli ialah salah bentuk pikiran yg nyata dari terhadap merek yg ada pada suatu periode. Chung et al. (2012) menyimpulkan jika minat pembelian bisa dipakai guna mengukur transformasi pelanggan pada perilaku 
pembelian pada produk tertentu, serta bisa dipakai sebagai indeks dalam memprediksi keputusan pembelian dari konsumen.

Pemberitaan yang terjadi mengenai kekurangan maupun kelebihan Bata sangat cepat menyebar dengan adanya internet. Menurut Abdullah (2015), menyimpulkan jika perkembangan internet sudah mempengaruhi kemampuan komunikasi serta sudah menguatkan skala serta cakupan komunikasi pada mulut ke mulut disebut $W O M$, serta sudah mempresentasikan arti dasar dari $E$-WOM menjadi sesuatu konsep yg baru dari WOM yg memberi transparansi serta akses yg mudah guna mendapatkan informasi dengan internet.

Kemajuan dari teknologi informasi, membuat kian banyak dari konsumen melihat informasi yg dibutuhkan akan suatu produk sebelum kemudian membeli seperti melalui Openrice.com (review sharing plat-form), TokoBagus (online shop), KASKUS (online community), blog, Facebook (social media), karena tingkat aksebilitas serta jangkauannya yang lebih luas dan mudah.

Dampak positif dalam melakukan kegiatan E-WOM tentu bisa memainkan peran yang sangat besar dalam melihat ketertarikan konsumen mengenai merek yang baru dipasar. Sebaliknya jika negatif juga bisa menimbulkan persepsi mengenai merek yang dibeli dan mengubah minat beli konsumen dalam membeli sebuah produk. Penelitian yg telah dilaksanakan Elseidi \& El-Baz (2016) menyimpulkan jika $E-W O M$ mempengaruhi positif pada citra merek, sikap merek serta minat beli konsumen. Menurut Adriyati \& Indriani (2017) menyatakan jika $E$ WOM mempengaruhi positif pada minat beli, yang dimana semakin positif serta baiknya review seseorang di blog serta web kemudian menimbulkan minat beli yg tinggi pada suatu merek. Menurut Torlak et al. (2014) menyimpulkan jika E-WOM tidak mempengaruhi serta tidak memperlihatkan hasil yg positif pada minat beli.

Menurut Semuel dan Lianto (2014), menyatakan konsumen merupakan bagian yg mempunyai potensi bagus pada pemberitaan tentang produk. Bermacam macam informasi yg berguna serta bermacam pendapat orang yg baik terkait pada suatu merek kemudian $E-W O M$ bisa membuat timbulnya suatu citra merek. Citra merek mempunyai sifat khas, dan sifat khas inilah yang membedakan produk yang satu berbeda dengan produk yang lainnya walaupun sejenis. Permintaan akan sebuah produk barang yang semakin berkualitas membuat perusahaan yang bergerak di berbagai bidang usaha berlomba-lomba meningkatkan dan mempertahankan citra merek produk yang mereka miliki. Menurut Kotler dan Keller (2012:274) medefinisikan citra merek merupakan persepsi masyarakat terhadap perusahaan atau produknya. Dimana menurut Adil (2012) fungsi utama citra merek adalah untuk menjawab pertanyaan tentang bagaimana konsumen memilih diantara merek alternatif setelah melakukan pengambilan informasi.

Citra merek yg bagus bisa menumbuhkan nilai-nilai emosional dari konsumen, dikarenakan hal tersebut perusahaan diharapkan menambahkan citra merek mereka dikarenakan nilai emosional bisa membuat terjadinya persepsi yg positif terhadap produk yg kemudian membuat minat beli (Weli dan Rahyuda, 2016). Sangadji dan Sopiah (2013:327) mendefinisikan bahwa citra merek dapat positif maupun negatif, tergantung pada persepsi seseorang terhadap merek. Kotler dan Keller (2012:241) mengartikan citra merek merupakan suatu nama, tanda, istilah, desain, simbol, serta kombinasi keseluruhan yg dimaksudkan guna 
mengidentifikasi suatu barang serta jasa akan satu penjual serta sekelompok penjual serta guna membedakannya dibanding pesaingnya. Fahrian (2015) menyimpulkan jika citra merek adalah hasil pandangan serta persepsi konsumen pada merek, yg berdasar dari pertimbangan serta persepsi yg akurat akan suatu merek. Moksaoka (2016) menyimpulkan jika citra merek mengasi jaminan pada konsumen tentang produk itu dan kemudian minat beli konsumen dgn produk serta merek tertentu bertambah diakibatkan konsumen tak mempunyai kekhawatiran akan produk dengan merek itu. Tariq et al. (2017) menyimpulkan jika citra merek memediasi penuh antara $E-W O M$ pada minat beli.

E-WOM yang mengandung nilai informasi positif secara tidak langsung dapat meningkatkan citra merek akan suatu produk bagi konsumen. Penelitian yg dilaksanakan oleh Elseidi \& El-Baz (2012) yang berjudul "Electronic Word of Mouth Effects on Consumers Brand Attitudes, Brand Image and Purchase Intention: An Empirical Study in Egypt." menunjukkan bahwa E-WOM memiliki pengaruh positif dan signifikan terhadap citra merek. Hasil penelitian yang sama juga didukung oleh penelitian dari Luong et al. (2017); Tariq et al. (2017).

Samuel dan Lianto (2014) dalam penelitiannya tentang Analisis E-WOM, Brand Image, Brand Trust dan Minat Beli Produk Smartphone di Surabaya menyebutkan bahwa E-WOM berpengaruh terhadap Brand Image, yang dimana didukung dengan hasil penelitian bahwa ketika penilaian responden terhadap $E$ $W O M$ semakin baik menyebabkan semakin tingginya citra merek suatu merek. Adriyati \& Indriani (2017) memberikan hasil jika E-WOM mempengaruhi positif pada Brand Image produk kosmetik Wardah. Anggitasari (2016) menyimpulkan jika ada pengaruh yg positif serta signifikan $E$-WOM pada citra merek akan produk Smartphone Iphone. Dari hasil penelitian sebelumnya, maka dapat ditarik hipotesis:

$\mathrm{H}_{1}$ : $\quad$-WOM berpengaruh positif dan signifikan terhadap citra merek.

Semakin baik review akan suatu produk di media sosial dan pernyataan tersebut positif kemudian membuat minat beli yg tinggi akan suatu produk. E-WOM yang semakin baik akan mendorong konsumen untuk berniat melakukan pembelian. Penelitian yang dilakukan oleh Elseidi and El-Baz (2016) yang berjudul "Electronic Word of Mouth Effects on Consumers Brand Attitudes, Brand Image and Purchase Intention: An empirical Study in Egypt" menunjukkan bahwa EWOM memiliki pengaruh positif dan signifikan terhadap minat beli. Hasil penelitian yang sama juga didukung oleh penelitian dari Tariq et al. (2017); Cong dan Zheng (2017).

Sarah \& Rubiyanti (2016) menyimpulkan jika E-WOM mempengaruhi signifikan pada minat beli pada Café Du7le Bandung. Anggitasari (2016) dengan penelitiannya tentang Pengaruh E-WOM Terhadap Brand Image dan Brand Trust, serta dampaknya pada Minat Beli Produk Smartphone Iphone menemukan jika $E$ $W O M$ mempengaruhi signifikan pada minat beli, yang dimana semakin bagus $E$ WOM maka semakin tinggi minat beli konsumen terhadap iPhone. Adriyati \& Indriani (2017) menyimpulkan hasil jika E-WOM mempengaruhi positif pada minat beli, yg dimana semakin positif serta bagus review seseorang di blog serta web kemudian mengakibatkan minat beli yg tinggi akan suatu produk kosmetik Wardah, 
Penelitian dengan hasil sama juga dikemukakan oleh penelitian dari Semuel dan Lianto (2014). Berdasarkan hasil penelitian terdahulu, maka bisa dibuat hipotesis:

$\mathrm{H}_{2}$ : $\quad$ E-WOM berpengaruh positif dan signifikan terhadap minat beli.

Citra merek yg baik akan suatu produk berupa barang maka minat beli konsumen akan semakin tinggi. Penelitian yang dilakukan oleh Elseidi and El-Baz (2016) yang berjudul "Electronic Word of Mouth Effects on Consumers Brand Attitudes, Brand Image and Purchase Intention: An empirical Study in Egypt" menunjukkan bahwa citra merek memiliki pengaruh positif dan signifikan terhadap minat beli.

Maghfiroh dkk. (2016) dengan penelitiannya tentang Pengaruh Citra Merek Terhadap Minat Beli dan Keputusan Pembelian menemukan bahwa citra merek memiliki pengaruh signifikan terhadap minat beli, yang dimana citra merek naik atau meningkat maka akan mengakibatkan minat beli konsumen juga meningkat. Anggitasari (2016) dengan penelitiannya tentang Pengaruh E-WOM Terhadap Brand Image dan Brand Trust, serta Dampaknya pada Minat Beli Produk Smartphone Iphone menemukan citra merek mempengaruhi positif serta signifikan pada minat beli, yg dimana semakin tinggi citra merek yg dirasakan konsumen pada produk smartphone iPhone kemudian semakin besar minat konsumen untuk membeli produk tersebut. Priyono dkk. (2016) menemukan citra merek mempengaruhi positif serta signifikan pada minat beli, yang dimana semakin baiknya serta besarnya citra merek suatu produk yg kemudian minat beli konsumen juga semakin membesar.

Fahrian dkk. (2015) tentang Pengaruh Citra Merek, Lokasi, Kepercayaan dan Kualitas Pelayanan Terhadap Minat Membeli BBM menemukan bahwa terdapat pengaruh antara citra merek terhadap minat beli, artinya apabila citra merek meningkat maka minat beli akan meningkat. Menurut Kamilah dan Wahyuti (2017) menyimpulkan jika citra merek mempengaruhi signifikan serta positif pada minat beli. Menurut Ningrum (2016) menyimpulkan jika citra merek mempengaruhi signifikan pada minat beli di Rokok Sampoerna. Dari hasil penelitian sebelumnya, maka dapat ditarik hipotesis:

$\mathrm{H}_{3}$ : Citra Merek berpengaruh positif dan signifikan terhadap minat beli.

Penelitian yang dilakukan oleh Siswanto (2017) tentang E-WOM berpengaruh signifikan secara langsung maupun tidak langsung terhadap minat beli melalui citra merek sebagai variabel mediasi, yang dimana pengaruh $E$-WOM terhadap minat beli lebih efektif saat terjadi langsung tanpa melalui citra merek, hasil penelitian ini juga menunjukkan bahwa citra merek sebagai variabel mediasi komplementer. Menurut Cynthiadewi \& Hatammimi (2014) yg mendapat hasil efek mediasi citra merek mempengaruhi positif pada variabel $E-W O M$ dan minat beli. Artinya, bagi calon konsumen $E$-WOM mempunyai dampak yg penting sebelum melaksanakan pembelian melalui informasi yg mereka temukan dari $E-W O M$, akan lebih gampang mereka dalam membeli produk dikemudian hari serta dengan memanfaat informasi visual ini bisa meningkatkan pemahaman total akan manfaat produk. Menurut Tariq et al. (2017) menyimpulkan jika citra merek menjadi mediator dalam E-WOM pada minat beli. Menurut Anggitasari (2016) menyimpulkan terdapat pengaruh positif serta signifikan anatara E-WOM pada 
minat beli melewati citra merek pada Smartphone Merek Iphone. Menurut Elseidi \& El-Baz (2016) menyimpulkan jika citra merek bisa memediasi pengaruh variabel E-WOM pada variabel minat beli. Menurut Adriyati \& Indriani (2017) pada penelitiannya menyibutkan jika terdapatnya pengaruh $E-W O M$ pada minat beli yg dimediasi dengan citra merek pada Kosmetik Wardah. Dari hasil penelitian sebelumnya, maka dapat ditarik hipotesis:

$\mathrm{H}_{4}$ : Citra Merek mampu dalam memediasi E-WOM dengan minat beli.

\section{METODE PENELITIAN}

Penelitian ini menggunakan pendekatan kuantitatif yg berbentuk asosiatif. Lokasi penelitian ini dilakukan di kota Denpasar. Obyek dalam penelitian ini adalah minat beli, E-WOM dan citra merek pada produk sepatu merek Bata di Kota Denpasar. Variabel endogen dalam penelitian ini adalah minat beli. Variabel eksogen dalam penelitian ini adalah ini adalah E-WOM. Variabel intervening dalam penelitian ini adalah Citra Merek (M). Populasi dalam penelitian ini adalah masyarakat di Kota Denpasar yang jumlahnya tidak dapat diidentifikasi. Sampel dari penelitian ini adalah 130 responden. Metode pengumpulan data dalam penelitian ini adalah metode survei dengan menggunakan kueisioner yang disebarkan melalui media sosial. Data dikumpulkan menggunakan instrumen penelitian berupa kuesioner dan observasi non perilaku. Kuesioner terdiri atas dua bagian yaitu bagian yang menanyakan identitas responden dan bagian yang menyajikan sejumlah indikator variabel penelitian yang dimintakan pendapat kepada responden.

Uji validitas bertujuan untuk memeriksa apakah indikator pada kuesioner sebagai alat ukur sudah tepat sehingga mendapatkan hasil yang valid. Valid berarti instrumen tersebut dapat digunakan untuk mengukur apa yang seharusnya diukur (Sugiyono, 2017:198). Instrumen yang reliabel adalah instrumen yang bila digunakan beberapa kali untuk mengukur obyek yang sama, akan menghasilkan data yang sama (Sugiyono, 2017:198). Suatu variabel dikatakan reliabel jika memberikan nilai Alpha Cronbach $\geq 0,60$. Terdapat dua teknik analisis yang digunakan dalam penelitian ini yaitu statistik deskriptif dan statistik inferensial. Statisktik Deskriptif adalah statistik yang digunakan untuk menganalisa data dengan cara mendeskripsikan atau menggambarkan data yang telah terkumpul sebagaimana adanya tanpa bermaksud membuat kesimpulan yang berlaku untuk umum atau generalisasi (Sugiyono, 2017:147).

Statistik inferensial adalah teknik statistik yang digunakan untuk menganalisis data sampel dan hasilnya diberlakukan untuk populasi (Sugiyono, 2016:170). Uji normalitas dilakukan untuk menguji apakah residu dalam sebuah model regresi yang dibuat mempunyai distribusi normal atau tidak. Uji multikolinearitas digunakan untuk menguji apakah model regresi ditemukan adanya korelasi antar variabel independent. Uji heteroskedastisitas bertujuan untuk menguji apakah dalam model regresi terjadi ketidaksamaan varians dari residual satu pengamatan ke pengamatan yang lain (Ghozali, 2016: 134).

Penelitian ini menggunakan teknik analisis jalur (path analysis) untuk menjawab rumusan hipotesis yang telah dibuat. Langkah-langkah dalam 
menganalisis data dengan menggunakan path analysis menurut Riduwan dan Kuncoro (2011:152) adalah sebagai berikut. Merumuskan hipotesis dan menetapkan persamaan structural, menghitung koefisien jalur, nilai error dan determinasi total, pengaruh tidak langsung (indirect effect), pengaruh total (total effect), menguji ketepatan model struktural, menghitung koefisien jalur secara individual, meringkas dan menyimpulkan.

Uji sobel merupakan alat analisis untuk menguji signifikansi hubungan tidak langsung antara variabel eksogen $E$-WOM $(\mathrm{X})$ terhadap variabel endogen yaitu Minat Beli (Y) melalui variabel mediasi Citra Merek (M). Untuk pengambilan keputusan dalam pengujian hipotesis, maka model hipotesis dalam penelitian ini adalah sebagai berikut. Merumuskan hipotesis dengan menggunakan model hipotesis, taraf nyata, alpha $=0,05$, daerah kritis, statistik uji dilakukan dengan menghitung nilai $\mathrm{S}_{\mathrm{ab}}$ dan $\mathrm{z}$.

Pengujian hipotesis mediasi dilakukan dengan metode VAF (Hair et al. dalam Solihin dan Ratmono, 2013). Prosedur ini dibagi menjadi dua bagian pengujian mediasi. Untuk pengujian mediasi variabel citra merek (Y) pada pengaruh $E-W O M$ (X) terhadap minat beli (M). Pertama, pengaruh langsung harus signifikan (a) saat variabel citra merek $(\mathrm{M})$ belum dimasukkan ke dalam model. Kedua, setelah variabel citra merek (M) dimasukkan ke dalam model, maka pengaruh tidak langsung ( $\mathrm{b}$ x c) harus signifikan. Setiap jalur yaitu b dan $\mathrm{c}$ harus signifikan untuk memenuhi kondisi ini.

\section{HASIL DAN PEMBAHASAN}

Responden dalam penelitian ini digambarkan secara umum dengan menyajikan karakteristik dari beberapa variabel demografi yaitu jenis kelamin, umur, pendidikan terakhir, dan pekerjaan responden. Berdasarkan data karakteristik responden berdasarkan Tabel 4. dapat dilihat menurut pengelompokan jenis kelamin, responden perempuan sebesar $63,1 \%$, sedangkan responden laki-laki sebesar 36,9\%. Jika dilihat dari data karakteristik usia responden, dapat dilihat bahwa mayoritas responden berusia 18-23 Tahun sebanyak 95,4\%, responden berusia $24-29$ Tahun sebanyak 3,1\%, lalu responden berusia 36-41 Tahun sebanyak 1,5\%, dan tidak ada responden berusia 30-35 Tahun diatas 41 Tahun.

Jika dilihat dari data karakteristik pendidikan responden, dapat dilihat bahwa mayoritas responden memiliki pendidikan terakhir SMA/SMK sederajat 78,5\%, responden diploma $6,2 \%$, dan responden $\mathrm{S} 1$ 15,4\%. Jika dilihat dari data karakteristik pekerjaan responden, dapat dilihat bahwa mayoritas responden memiliki sebagai mahasiswa/i sebanyak $83,1 \%$, responden pegawai negeri sipil sebanyak $1,5 \%$, responden pegawai swasta sebanyak $8,5 \%$, responden wiraswasta sebanyak 4,6\%, dan responden lainnya sebanyak $2,3 \%$.

Hasil uji validitas instumen disajikan dalam Tabel 5. dibawah menunjukkan variabel minat beli memiliki pearson correlation $0,745-0,905$ $(>0,30)$, hal ini berarti bahwa pernyataan tersebut juga valid. Variabel E-WOM memiliki pearson correlation dari 0,829-0,925 (>0,30), hal ini berarti bahwa pernyataan tersebut valid. Variabel Citra Merek memiliki pearson correlation 
dari $0,779-0,915(>0,30)$, hal ini berarti bahwa pernyataan dalam kuesioner adalah valid.

Hasil uji validitas instrumen disajikan dalam Tabel 6. yang menunjukkan bahwa ketiga instrumen penelitian yaitu minat beli, E-WOM, dan citra merek memiliki koefisien cronbach's alpha yang lebih besar dari angka 0,60 sehingga pernyataan pada kuesioner dapat dikatakan reliabel.

Tabel 8. dibawah menunjukkan bahwa rata - rata skor tanggapan responden mengenai variabel minat beli yang terdiri dari ketertarikan, keinginan, keyakinan, mempertimbangkan untuk membeli, memiliki produk sebesar 3,74 yang berarti secara keseluruhan responden setuju dengan pernyataan-pernyataan terhadap variabel minat beli.

Tabel 4.

Karakteristik Responden

\begin{tabular}{|c|c|c|c|c|}
\hline No & Variabel & Klasifikasi & Jumlah & Persentase \% \\
\hline \multirow[t]{3}{*}{1} & Jenis Kelamin & Laki-laki & 48 & 36,9 \\
\hline & & Perempuan & 82 & 63,1 \\
\hline & Total & & 130 & 100,00 \\
\hline \multirow[t]{6}{*}{2} & Usia & $18-23$ Tahun & 124 & 95,4 \\
\hline & & 24 - 29 Tahun & 4 & 3,1 \\
\hline & & 30 - 35 Tahun & 0 & 0,0 \\
\hline & & 36 - 41 Tahun & 2 & 1,5 \\
\hline & & diatas 41 Tahun & 0 & 0,0 \\
\hline & Total & & 130 & 100 \\
\hline \multirow[t]{4}{*}{4} & Pendidikan & SMA & 102 & 78,5 \\
\hline & Terakhir & Diploma & 8 & 6,2 \\
\hline & & S1 & 20 & 15,4 \\
\hline & Total & & 130 & 100 \\
\hline \multirow[t]{6}{*}{3} & Pekerjaan & Mahasiswa/i & 108 & 83,1 \\
\hline & & Pegawai Negeri Sipil & 2 & 1,5 \\
\hline & & Pegawai Swasta & 11 & 8,5 \\
\hline & & Wiraswasta & 6 & 4,6 \\
\hline & & Lainnya & 3 & 2,3 \\
\hline & Total & & 130 & 100 \\
\hline
\end{tabular}

Sumber: Asosiasi Persepatuan Indonesia (Aprisindo), 2017

Tabel 9. dibawah menunjukkan bahwa rata-rata skor tanggapan responden mengenai variabel $E-W O M$ yang terdiri dari tie strength, homophily, trust, normative influence, dan informative influence adalah sebesar 3,67 yang berarti secara keseluruhan responden setuju terhadap pernyataan-pernyataan pada variabel E-WOM.

Tabel 10. diatas menunjukkan bahwa rata-rata skor tanggapan responden mengenai variabel citra merek yang terdiri dari daya ingat konsumen akan merek, kualitas produk, citra produk, dan keunikan adalah sebesar 3,66 yang berarti secara 
keseluruhan responden setuju terhadap pernyataan-pernyataan pada variabel citra merek.

Tabel 5.

Hasil Uji Validitas

\begin{tabular}{|c|c|c|c|c|}
\hline No & Variabel & $\begin{array}{c}\text { Instrum } \\
\text { en }\end{array}$ & $\begin{array}{c}\text { Pearson } \\
\text { Correlation }\end{array}$ & Keterangan \\
\hline \multirow{3}{*}{1} & \multirow{3}{*}{$\begin{array}{l}\text { Minat Beli } \\
\text { (Y) }\end{array}$} & Y.1 & 0,905 & Valid \\
\hline & & Y.2 & 0,876 & Valid \\
\hline & & Y.3 & 0,745 & Valid \\
\hline \multirow{5}{*}{2} & \multirow{6}{*}{$\begin{array}{c}E-W O M \\
\quad(\mathrm{X})\end{array}$} & Y.4 & 0,886 & Valid \\
\hline & & X.1 & 0,909 & Valid \\
\hline & & X.2 & 0,925 & Valid \\
\hline & & X.3 & 0,829 & Valid \\
\hline & & X.4 & 0,838 & Valid \\
\hline & & X.5 & 0,843 & Valid \\
\hline \multirow{4}{*}{3} & \multirow{4}{*}{$\begin{array}{l}\text { Citra Merek } \\
\text { (M) }\end{array}$} & M.1 & 0,830 & Valid \\
\hline & & M.2 & 0,779 & Valid \\
\hline & & M.3 & 0,915 & Valid \\
\hline & & M.4 & 0,836 & Valid \\
\hline
\end{tabular}

Sumber: Asosiasi Persepatuan Indonesia (Aprisindo), 2017

Tabel 6.

Hasil Uji Reliabilitas

\begin{tabular}{ccc}
\hline Variabel & Cronbach's Alpha & Keterangan \\
\hline Minat Beli $(\mathrm{Y})$ & 0,875 & Reliabel \\
$E-W O M(\mathrm{X})$ & 0,918 & Reliabel \\
Citra Merek $(\mathrm{M})$ & 0,855 & Reliabel
\end{tabular}

Sumber: Asosiasi Persepatuan Indonesia (Aprisindo), 2017

Tabel 7.

Rentang Penilaian Jawaban Responden

\begin{tabular}{ccc}
\hline No. & Rentang & Kriteria \\
\hline 1. & $1,00-1,79$ & Sangat Tidak Baik \\
2. & $1,80-2,59$ & Tidak Baik \\
3. & $2,60-3,39$ & Cukup Baik \\
4. & $3,40-4,19$ & Baik \\
5. & $4,20-5,00$ & Sangat Baik
\end{tabular}

Sumber: Asosiasi Persepatuan Indonesia (Aprisindo), 2017 
Tabel 8.

Distribusi Jawaban Responden Terhadap Variabel Minat Beli

\begin{tabular}{|c|c|c|c|c|c|c|c|c|}
\hline \multicolumn{6}{|c|}{ Skor Jawaban } & \multirow{2}{*}{$\begin{array}{c}\text { Jumlah } \\
\text { Skor }\end{array}$} & \multirow{2}{*}{$\begin{array}{l}\text { Rata- } \\
\text { Rata }\end{array}$} & \multirow{2}{*}{ Ket. } \\
\hline Indikator & STS & TS & $\mathbf{N}$ & $\mathbf{S}$ & SS & & & \\
\hline Y.1 & 1 & 9 & 39 & 53 & 28 & 488 & 3,75 & Baik \\
\hline Y.2 & 2 & 6 & 40 & 63 & 19 & 481 & 3,70 & Baik \\
\hline Y.3 & 2 & 4 & 39 & 61 & 24 & 491 & 3,78 & Baik \\
\hline Y.4 & 1 & 8 & 41 & 59 & 21 & 481 & 3,70 & Baik \\
\hline \multicolumn{6}{|c|}{ Minat Beli } & 1943 & 3,74 & Baik \\
\hline
\end{tabular}

Sumber: Asosiasi Persepatuan Indonesia (Aprisindo), 2017

Tabel 9.

Distribusi Jawaban Responden Terhadap Variabel $E$-WOM

\begin{tabular}{|c|c|c|c|c|c|c|c|c|}
\hline \multicolumn{6}{|c|}{ Skor Jawaban } & \multirow{2}{*}{$\begin{array}{c}\text { Jumlah } \\
\text { Skor }\end{array}$} & \multirow{2}{*}{$\begin{array}{l}\text { Rata- } \\
\text { Rata }\end{array}$} & \multirow{2}{*}{ Ket. } \\
\hline Indikator & STS & TS & $\mathbf{N}$ & $\mathbf{S}$ & SS & & & \\
\hline X.1 & 1 & 11 & 38 & 62 & 18 & 475 & 3,65 & Baik \\
\hline X.2 & 1 & 9 & 42 & 62 & 16 & 473 & 3,64 & Baik \\
\hline X.3 & 1 & 10 & 43 & 54 & 22 & 476 & 3,66 & Baik \\
\hline X.4 & 1 & 10 & 32 & 66 & 21 & 486 & 3,74 & Baik \\
\hline X.5 & 3 & 12 & 35 & 55 & 25 & 477 & 3,67 & Baik \\
\hline \multicolumn{6}{|c|}{ E-WOM } & 2387 & 3,67 & Baik \\
\hline
\end{tabular}

Sumber: Asosiasi Persepatuan Indonesia (Aprisindo), 2017

Tabel 10.

Distribusi Jawaban Responden Terhadap Variabel Citra Merek

\begin{tabular}{|c|c|c|c|c|c|c|c|c|}
\hline \multicolumn{6}{|c|}{ Skor Jawaban } & \multirow{2}{*}{$\begin{array}{c}\text { Jumlah } \\
\text { Skor }\end{array}$} & \multirow{2}{*}{$\begin{array}{l}\text { Rata- } \\
\text { Rata }\end{array}$} & \multirow{2}{*}{ Ket. } \\
\hline Indikator & STS & TS & $\mathbf{N}$ & $\mathbf{S}$ & SS & & & \\
\hline M.1 & 1 & 12 & 32 & 48 & 37 & 496 & 3,83 & Baik \\
\hline M.2 & 4 & 22 & 44 & 45 & 15 & 435 & 3,35 & Baik \\
\hline M.3 & 1 & 5 & 37 & 62 & 25 & 495 & 3,81 & Baik \\
\hline M.4 & 3 & 7 & 43 & 54 & 23 & 477 & 3,67 & Baik \\
\hline \multicolumn{6}{|c|}{ Citra Merek } & 1905 & 3,66 & Baik \\
\hline
\end{tabular}

Sumber: Asosiasi Persepatuan Indonesia (Aprisindo), 2017

Tabel 11.

Hasil Uji Normalitas Struktur 1

\begin{tabular}{lc}
\hline & Unstandardized Residual \\
\hline $\mathrm{N}$ & 130 \\
Kolmogorov-Smirnov Asymp. Sig. (2-tailed) & 0.074 \\
\hline Sumber: Asosiasi Persepatuan Indonesia (Aprisindo), 2017
\end{tabular}

Tabel 11. menjelaskan jika nilai Kolmogorov-Smirnov Asymp. Sig. (2-tailed) senilai 0,074 . Hasil tersebut mengindikasikan bahwa model persamaan regresi 
tersebut berdistribusi normal karena nilai Asymp. Sig. (2-tailed) lebih besar dari 0,05 .

Tabel 12.

Hasil Uji Normalitas Struktur 2

\begin{tabular}{lc}
\hline & Unstandardized Residual \\
\hline $\mathrm{N}$ & 130 \\
Kolmogorov-Smirnov Asymp. Sig. (2-tailed) & 0.092 \\
\hline
\end{tabular}

Sumber: Asosiasi Persepatuan Indonesia (Aprisindo), 2017

Tabel 12. menjelaskan jika nilai Kolmogorov-Smirnov nilai Asymp. Sig. (2tailed) senilai 0,092. Hasil tersebut mengindikasikan bahwa model persamaan regresi tersebut berdistribusi normal karena nilai Asymp. Sig. (2-tailed) lebih besar dari 0,05 .

Tabel 13.

Hasil Uji Multikolinearitas

\begin{tabular}{llcc}
\hline \multicolumn{1}{c}{ Persamaan Struktur } & \multicolumn{1}{c}{ Variabel } & Tolerance & VIF \\
\hline $\mathrm{M}=\beta_{1} \mathrm{X}+\mathrm{e}_{1}$ & $E-W O M(\mathrm{X})$ & 1.000 & 1.000 \\
$\mathrm{Y}=\beta_{2} \mathrm{X}+\beta_{3} \mathrm{X}+\mathrm{e}_{2}$ & $E-W O M(\mathrm{X})$ & 0.198 & 5.062 \\
& Citra Merek (M) & 0.198 & 5.062 \\
\hline
\end{tabular}

Sumber: Asosiasi Persepatuan Indonesia (Aprisindo), 2017

Didasarkan atas Tabel 13. bisa diperlihatkan jika nilai tolerance dan VIF dari variabel word of mouth serta citra merek memperlihatkan nilai tolerance pada setiap variabel melebihi nilai $10 \%$ atau nilai VIF lebih rendah dari $0,10 \mathrm{yg}$ mengartikan model persamaan regresi tidak terdapat multikolinearitas.

Berdasarkan Tabel 14. dan 15. dibawah, dapat dilihat bahwa nilai signifikansi dari variabel $E$-WOM sebesar 0,232. Nilai tersebut lebih besar dari 0,05 yang berarti tidak terdapat pengaruh antara variabel bebas terhadap absolute residual. E-WOM sebesar 0,345 dan variabel dari citra merek sebesar 0,983. Nilai tersebut lebih besar dari 0,05 yang berarti tidak terdapat pengaruh antara variabel bebas terhadap absolute residual.

Tabel 14.

Hasil Uji Heteroskedastisitas Struktur 1

\begin{tabular}{lllcccc}
\hline & & \multicolumn{2}{c}{$\begin{array}{c}\text { Unstandardized } \\
\text { Coefficients }\end{array}$} & $\begin{array}{c}\text { Standardized } \\
\text { Coefficients }\end{array}$ & t & Sig. \\
\cline { 3 - 7 } Model & B & Std. & Error & Beta & \\
\hline 1 & (Constant) & 1.507 & .378 & & 3.987 & .000 \\
& $E-W O M$ & -.024 & .020 & -.106 & -1.201 & .232 \\
\hline
\end{tabular}

Sumber: Asosiasi Persepatuan Indonesia (Aprisindo), 2017 
Tabel 15.

Hasil Uji Heteroskedastisitas Struktur 2

\begin{tabular}{llccccc}
\hline & & \multicolumn{2}{c}{$\begin{array}{c}\text { Unstandardized } \\
\text { Coefficients }\end{array}$} & $\begin{array}{c}\text { Standardized } \\
\text { Coefficients }\end{array}$ & t & Sig. \\
\cline { 3 - 7 } Model & & B & Std. Error & Beta & & \\
\hline 2 & (Constant) & 1.876 & .359 & & 5.218 & .000 \\
& $E-W O M$ & -.041 & .043 & -.186 & -.948 & .345 \\
& Citra Merek & -.001 & .051 & -.004 & -.021 & .983 \\
\hline
\end{tabular}

Sumber: Asosiasi Persepatuan Indonesia (Aprisindo), 2017

Tabel 16.

Hasil Analisis Jalur Sub-Struktural 1

\begin{tabular}{lccccc}
\hline \multicolumn{1}{c}{ Variabel } & Unstandardized Coefficients & $\begin{array}{c}\text { Standardized } \\
\text { Coefficients }\end{array}$ & t hitung & $\begin{array}{c}\text { Sig. uji } \\
\text { t }\end{array}$ \\
\hline \multicolumn{7}{c}{ Constant) } & $\mathrm{B}$ & Std. Error & Beta & & \\
E-WOM (X) & 1.000 & .611 & & 1.638 & .104 \\
R Square & .744 & .033 & .896 & 22.802 & .000 \\
F Statistik & 0,802 & & & & \\
Signifikansi Uji & 519,910 & & & & \\
F & 0,000 & & & \\
Sumber: Asosiasi Persepatuan Indonesia (Aprisindo), 2017
\end{tabular}

Nilai dari koefisien regresi variabel orientasi pasar adalah positif kemudian nilai signifikansi uji t lebih rendah dr 0,05. Ini memperlihatkan jika variabel $E$ $W O M$ mempunyai pengaruh yg positif serta signifikan pada variabel citra merek. Besarnya pengaruh dari variabel bebas pada variabel terikat yg diperlihatkan oleh nilai determinasi total (R Square) senilai 0,802 memiliki arti jika sebesar 80,2\% variasi citra merek dipenggaruhi variasi $E$-WOM, kemudian sisanya sebesar 19,8 diperjelas oleh faktor lain yg tidak terdapat di model.

Nilai dari koefisien regresi masing-masing variabel bebas mempunyai nilai positif dgn nilai signifikansi uji t lebih rendah 0,050 . Hal ini memperlihatkan jika semua variabel bebas mempengaruhi positif serta signifikan pada variabel terikat. Besar pengaruh dari variabel bebas pada variabel terikat yg diperlihatkan oleh nilai determinasi total (R Square) senilai 0,769 memiliki arti jika senilai 76,9\% variasi minat beli dipengarruhi oleh variasi $E-W O M$ serta citra merek, kemudian sisanya senilai $23,1 \%$ diperjelas dengan faktor lain yg tidak diterdapat di model.

Tabel 17.

Hasil Analisis Jalur Sub-Struktural 2

\begin{tabular}{lccccc}
\hline \multirow{2}{*}{ Variabel } & \multicolumn{2}{c}{$\begin{array}{c}\text { Cnstandardized } \\
\text { Coefficients }\end{array}$} & $\begin{array}{c}\text { Standardized } \\
\text { Coefficients }\end{array}$ & thitung & Sig. uji t \\
& $\mathrm{B}$ & Std. Error & Beta & & \\
\hline (Constant) & 2.471 & .627 & & 3.940 & .000 \\
E-WOM $(\mathrm{X})$ & .222 & .075 & .285 & 2.975 & .004 \\
Citra Merek $(\mathrm{M})$ & .573 & .090 & .612 & 6.382 & .000 \\
\hline Bersambung... & & & &
\end{tabular}


Lanjutan Tabel 17.

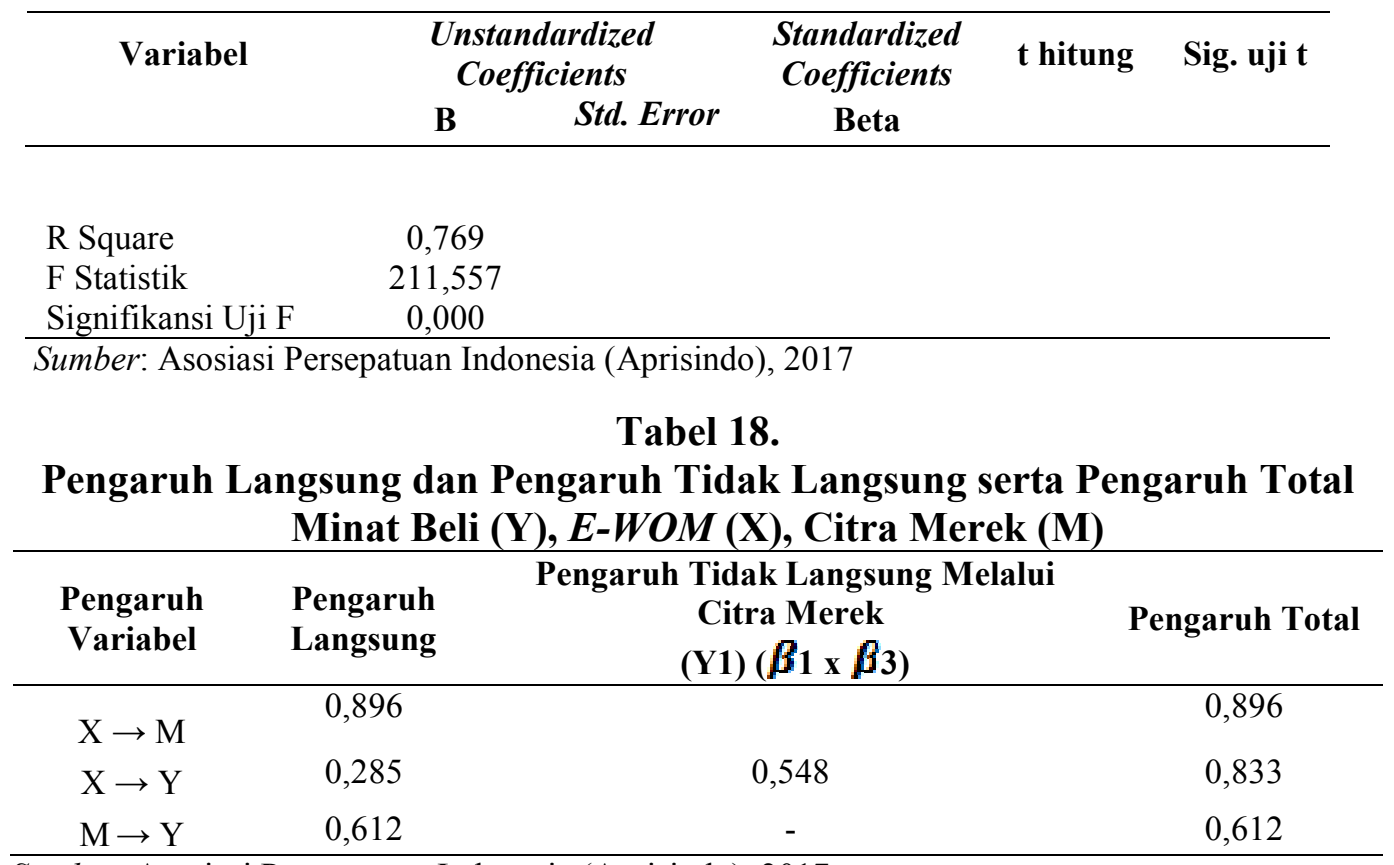

Sumber: Asosiasi Persepatuan Indonesia (Aprisindo), 2017

Tabel 18. Memperlihatkan jika pengaruh langsung E-WOM pada citra merek ialah senilai 0,896 . Pengaruh langsung variabel $E-W O M$ pada Minat beli senilai 0,285 . Pengaruh langsung variabel citra merek pada Minat beli senilai 0,612. Ini mengartikan jikaa variabel $E-W O M$ lebih besar terpengaruh oleh citra merek dibanding $E$-WOM. Yang kemudian pengaruh tak langsung dari variabel $E$-WOM pada Minat beli melewati citra merek senilai 0,548. Kemudian pengaruh total variabel $E$-WOM pada Minat beli melewati citra merek ialah senilai 0,833.

Didasarkan dari perhitungan, ditemukan nilai t hitung senilai 6,01 yg mengartikan lebih besar dibanding $1,96(6,01>1,96)$. Bisa disimpulkan jika citra merek bisa memediasi pengaruh $E-W O M$ pada minat beli. Hasil pengujian mediasi dengan metode VAF didapatkan hasil 0,397 atau 39,7 persen.

Didasarkan atas hasil penelitian yg diperoleh dlm analisis data bisa diketahui jika nilai sig. $t$ sebesar 0,000 dgn nilai koefisien beta senilai 0,896 . Nilai sig. $t$ yg diperlihatkan pada nilai $0,000<0,050$, kemudian bisa disimpulkan jika terdapat pengaruh positif serta signifikan antara $E-W O M$ pada citra merek. Berdasarkan hasil penelitian yg diperoleh dlm analisis data bisa diketahui jika nilai sig. $t$ senilai 0,004 dgn nilai koefisien beta senilai 0,285 . Nilai sig. t yg diperlihatkan nilai 0,004 $<0,050$, kemudian bisa disimpulkan jika ada pengaruh positif serta signifikan antara $E$-WOM pada minat beli. Didasarkan hasil penelitian yg didapat pada analisis data bisa diketahui jika nilai sig. $\mathrm{t}$ senilai 0,000 dgn nilai koefisien beta senilai 0,612 . Nilai sig. t yg menunjukan nilai $0,000<0,050$, kemudian bisa disimpulkan jika ada pengaruh positif serta signifikan antara citra merek pada minat beli. Didasarkan hasil yg didapatkan menggunakan uji sobel bisa diketahui jika utk signifikasi tidak langsung pengaruh E-WOM pada minat beli melalui citra merek didapatkan $\mathrm{Z}$ hitung yaitu senilai 6,01 lebih besar dibanding $\mathrm{z}$ tabel yaitu senilai 1,96. Itu memperlihatkan jika pelaksanaan $E$-WOM yg didukung oleh citra merek 
yg kuat, secara tidak langsung bisa mempengaruhi minat beli konsumen pada sepatu merek Bata.

\section{SIMPULAN DAN SARAN}

Didasarkan pembahasan hasil penelitian yg sudah dilaksanakan, kemudian bisa disimpulkan jika, E-WOM mempengaruh positif serta signifikan pada citra merek. Ini mengartikan jika baiknya komunikasi $E$-WOM yg terjadi kemudian akan semakin bagus juga citra merek yg tercipta. E-WOM mempengaruh positif serta signifikan pada minat beli. I mengartikan semakin tinggi intensitas komunikasi $E$ $W O M$ yg berlangsung akan menumbuhkan rasa percaya diri serta ingin tahu konsumen tentang hal yg dikomunikasikan secara online kemudian akan mengakibatkan minat beli konsumen. Citra merek mempengaruhi positif serta signifikan pada minat beli. Ini mengartikan jika semakin baik citra merek dari suatu perusahaan, kemudian semakin tinggi jg minat beli pada calon konsumen. Citra merek bisa memediasi pengaruh $E-W O M$ pada minat beli. Ini mengartikan citra merek bisa memberikan dampak yg lebih besar pada komunikasi $E-W O M$ yg terdapat pada minat beli.

Didasarkan hasil dari penelitian, pembahasan serta kesimpulan kemudian saran yg bisa diberikan ialah sebagai berikut, Bata harus lebih sering dalam melakukan promosi baik di media sosial secara online seperti melalui Openrice.com (review sharing plat-form), TokoBagus (online shop), KASKUS (online community), blog, Facebook (social media) dalam hal produknya, sehingga calon konsumen memiliki keinginan untuk mencari informasi mengenai produk Bata dengan mudah dan memiliki keinginan untuk membeli produk sepatu merek Bata. Bata harus dapat lebih meningkatkan dalam meyakinkan persepsi calon pembeli sepatu merek Bata di media sosial dengan pengguna yang sudah pernah menggunakan sepatu merek Bata, dengan cara mereview keunggulan produk Bata, baik dari segi keunggulan kualitas dan harga untuk meningkatkan minat beli bagi calon konsumen untuk memiliki produk sepatu merek Bata dengan menciptakan sesuatu yang baru baik dari desain yang tidak dimiliki pesaing lainnya. Manajemen dari Bata harus lebih meningkatkan kembali citra perusahaannya di benak konsumen dan harus bertindak dengan tanggap pada pemberitaan yang buruk apabila terjadi kesalahan pada produk yang dapat memberikan kerugian bagi konsumen. Salah satunya dapat dilakukan dengan memberikan berupa kompensasi pada konsumen mengenai keunggulam produk sepatu merek Bata dari pesaingnya. Untuk peneliti kemudian agar meningkatkan kualitas penelitian serta memperluas ruang lingkup penelitian kemudian menambah beberapa variabel lain.

\section{REFERENSI}

Abdullah, Battaineh. (2015). The Impact of Perceived E-WOM on Purchase Intention: The Mediating Role of Corporate Image. International Journal of Marketing Studies. Volume 7, No. 1, pp: 126-137.

Abubakar, M.A \& Pinar, S. (2016). E-WOM, e-Referrals and genders in the virtuals community. Marketings Intelligence \& Planning. Volume 34, No. 5, pp: 692710. 
Adil, Malikul. (2012). The Influence Of Brand Image On Sales. Journal of Basic and Applied Scientific Research. Volume 2. No. 4, pp: 3552-3586.

Adriyati, Rosmaya dan Farida Indriani. (2017). Pengaruh Electronic Word Of Mouth Terhadap Citra Merek Dan Minat Beli Pada Produk Kosmetik Wardah. Diponogoro Journal Of Management. Volume 6, No. 4, h. 1-14.

Anggitasari, Annisa Mayga. (2016). Pengaruh E-WOM Terhadap Brand Image Dan Brand Trust, Serta Dampaknya Pada Minat Beli Produk Smartphone Iphone (Studi Pada Masyarakat Di Yogyakarta). Jurnal Manajemen Bisnis Indonesia. Volume 5, No. 3, h. 266-275.

Asosiasi Persepatuan Indonesia. (2017). Merek yang Sukses Meraih Pangsa Pasar Terbesar di Dalam Negeri pada 2017. http://industri.bisnis.com/read/20180207/12/735561/pasar-sepatu-ini-diamerek-yang-jadi-raja-pasar- (Diakses pada tanggal 20 Oktober 2018).

Chung, C. H., Lin, C. Y. \& Chen, H. T (2012). A Study of Brands Perceptions, Advertisings Effectiveness and Relationships Quality on Purchase Intentions. Journal of Data Analysis, Volume 7, No. 5, pp: 137 - 158.

Cong, Y. and Zheng, Y. (2017) A Literature Review of the Influence of Electronic Word-of-Mouth on Consumer Purchase Intention. Open Journal of Business and Management, Volume 7, No. 5, pp. 543-549.

Cynthiadewi, P. R. dan Hatammimi, J. (2014) "The Influence of Electronic Word of Mouth Toward Brand Image and Purchase Intention of 13th Shoes," International Conference on Economics, Education and Humanities. Hal. 6670 .

Elseidi, R. I. \& E1-Baz, D. (2016). Electronics Words of Mouths Effects On Consumers' Brand Attitudes, Brand Image And Purchase Intention: An Empirical Study In Egypt. The Business and Management Review. Volume 7, No. 5, pp: 514-523.

Fahrian, Ferdy, Leonardo Budi Hasiolan, Andi Tri Haryono. (2015). Pengaruh Citra Merek, Lokasi, Kepercayaan Dan Kualitas Pelayanan Terhadap Minat Membeli Bbm Di Spbu Gasindo Mekar Putra Semarang. Journal of Management Volume 1, No. 1. h. 1-19.

Ghozali, I. (2016). Aplikasi Analisis Multivariate dengan Program IBM SPSS 21 Up Date PLS Regresi (Edisi 8). Semarang: Badan Penerbit Universitas Diponegoro

Goldsmith, R.E. and Horowitz, D. (2006). Measuring motivations for online opinion seeking. Journal of Interactive Advertising, Volume 6, No. 2, pp. 116 
Harun, Rasyid. (2017). Pengaruh Kualitas Layanan dan Pemanfaatan Teknologi Terhadap Kepuasan dan Loyalitas Pelanggan Go-Jek. Jurnal Ecodemika, Volume 1, No. 2, h. 210-223.

Kamilah, G. \& Wahyuati A. (2017). Pengaruh Labelisasi Halal Dan Brand Image Terhadap Keputusan Pembelian Melalui Minat Bali. Jurnal Ilmu Dan Riset Manajemen. Volume 6, No. 2, h. 1-18.

Kotler, Philip and Kevin Lane Keller, (2016): Marketing Management, 15th Edition New Jersey: Pearson Pretice Hall, Inc.

Luong, D. B. V., Le, Khao Huan \& Thi Huong Giang. (2017). The Impacts of Electronics Words of Mouths on Brands Image and Buyings Decisions: An Empiricals Study In Vietnam Tourisms. International Journal of Research Studies. Volume 6, No. 1, pp. 53-63.

Maghfiroh, A. A., Zainul, S. (2016). Pengaruh Citra Merek Terhadap Minat Beli Dan Keputusan Pembelian (Survei pada Mahasiswa Program Studi Administrasi Binis Tahun Angkatan 2013/2014 Fakultas Ilmu Adminisirasi Universitas Brawijaya Malang Pembeli Indosat). Jurnal Administrasi Bisnis. Volume 40, No. 1, h. 132-140.

Moksaoka, I. M. W. \& Rahyuda, I. K. (2016). Peran Brand Image Dalam Memediasi Country of Origin Terhadap Purchase Intention. E-Journal Manajamen Unud. Volume 5, No. 3, h. 1960-1716.

Ningrum, I. T. J. \& Nilowerdono, S. (2016), Pengaruh Event Dan Brand Image Terhadap Minat Beli Produk Rokok Sampoerna A Mild Pada PT HM Sampoerna Area Marketing Surabaya. E-Jurnal Manajemen Kinerja. Volume 2, No. 1, h. 57-69.

Priyono, E. A. T. Haryono \& Maria M. M. (2016). Analisis Pengaruh Citra Merek, Strategi Promosi, Atribut Produk, Harga Terhadap Minat Berkunjung Serta Pengaruhnya Terhadap Minat Beli (Studi Empiris Pada Pameran Computer Javamall Semarang). Journal of Management. Volume 2, No.2. h. 1-22.

Randi \& Heryanto, M. (2016). Pengaruh Citra Merek terhadap Minat Beli pada Makenen Fast Food Ayam Goreng (Studi pada Konsumen Texas Chicken Pekanbaru). Jurnal Online Mahasiswa Fakultas Ilmu Sosial dan Ilmu Poltik. Volume 3, No.2, h. 1-9.

Riduwan \& Kuncoro. (2011). Cara Menggunakan dan Mama/cat Path Analysis (Analisis Jalur). Bandung: Alfabeta.

Samuel, Hateneden dan Adi Suryanata Lianto. (2014). Pengaruh Analisis WOM, Brand lmage, Brand Trust dan Minat Beli Produk Smartphone di Surabaya. Jurnal Universitas Kristen Petra Surabaya. Volume 8, No. 2, h. 103-109. 
Sarah, Taste Marijke Siti den Rubiyanti, R. Nuraghi. (2016). Pengaruh Electronic Word of Mouth Terhadap Minat Beli Pada Café Du7le Bandung. eProceeding of Management. Volume 3, No. 2, h. 2087-2093.

Schiffman, L. G. \& Lazar K. (2008). Perilaku konsumen. Edisi 7. Jakarta: Indeks.

Siswanto, M \& M.F.S. Junaedi. (2017). Pengaruh Electronic Word of Mouth Pada Citra Merek dan Minat beli Pada Warunk Upnormal. Article. Fakultas Ekonomi Universitas Atma Jaya Yogyakarta. Hal. 1-13

Solihin, M. \& Ratmono, Dwi. (2013). Analisis SEM-PLS dengan WarpPLS 3.0. Yogyakarta: Penerbit Andi.

Sugiyono. (2016). Metode Penelitian Pendidikan (Pendekatan Kualitatitif Kuantitatif dan R\&D). Bandung; Alfabeta.

Sugiyono. (2017). Metode Penelitian Bisnis (Pendekatan Kuantitatif, Kualitatif, Kombinasi dan $R \& D)$. Bandung: Alfabeta.

Tariq, M. A. T., Abrar, M., Iqbal, A. (2017). E-WOM And Brand Awareness Impact on Consumer Purchase Intention: Mediating Role of Brand Image. Pakistan Administrative Review. Volume 1, No. 1, pp. 84-102.

Top Brand Awards. www.topbrand-award.com (Diakses pada tanggal 20 Oktober 2018).

Torlak, O., Oeknra B.Y., Tilsty M. A., Cengiz H \& Dulger M. F. (2014). The Effect of Electronic Word of Mouth on Brand Image and Purchase Intention: An Application Concerning Cell Phone Brands for Youth Consumers in Turkey. Journal of Marketing Development and Competitiveness. Volume 8, No.2. pp. 61-68.

Weli, I. M. \& I K. Rahyuda, (2016). Peran brand image dalam memediasi country of origin terhadap purchase intention. E-Jurnal Manajemen Universitas Udayana. Volume 5, No. 3, h. 1690-1716. 